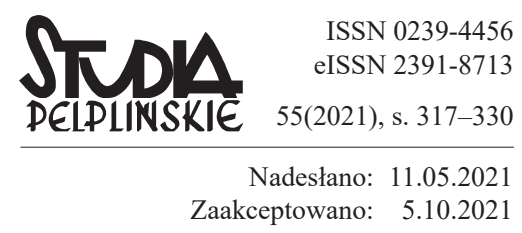

KS. ARTUR TYBUSZ

Uniwersytet Mikołaja Kopernika w Toruniu

arttyb_@poczta.onet.pl

ORCID: orcid.org/0000-0003-1941-1435

\title{
ŚWIĘTOŚĆ MAŁŻEŃSTWA I RODZINY W NAUCZANIU PAPIEŻA FRANCISZKA
}

DOI: http://dx.doi.org/10.12775/SPLP.2021.018

\begin{abstract}
Streszczenie
Niniejszy artykuł ma na celu ukazanie wartości, jaką stanowi chrześcijański ideał małżeństwa i rodziny w świetle nauczania papieża Franciszka. Temat naszej pracy został omówiony w trzech blokach tematycznych. W pierwszym bloku podjęliśmy próbę zdefiniowania słowa świętość, ukazując tym samym bogatą specyfikę tego terminu, aby następnie spojrzeć na tę kwestię w świetle świętości rodziny i małżeństwa. Ujęte w pierwszym i drugim etapie zagadnienia prowadzą nas do bloku trzeciego niniejszej pracy, w którym uwaga została skoncentrowana na praktycznych wskazaniach, które ukazują małżeństwo jako drogę prowadzącą do świętości.
\end{abstract}

Słowa kluczowe: papież Franciszek; świętość związu matżeńskiego; świętość rodziny

THE SANCTITY OF MARRIAGE

AND FAMILY IN POPE FRANCIS' TEACHING

\begin{abstract}
The aim of this paper was to present a value of a Christian ideal of marriage and family in Pope Francis' teaching. The subject of our work was discussed in three parts. In the first one, we attempted to define the meaning of sacredness by showing rich character of this term. Subsequently, we looked into this issue
\end{abstract}


regarding the sacredness of marriage and family. The problems in the first and the second stagess were an introduction to the third part, in which we focused on the practical issues, by showing a marriage as as a means to the sacredness.

Keywords: Pope Francis, sacredness of marriage, sacredness of family

W ostatnich czasach stajemy się świadkami coraz bardziej nasilających się ataków na chrześcijański ideał małżeństwa i rodziny. To właśnie rodzina w dzisiejszych czasach stała się miejscem zmasowanych aktów, które przybrały na sile,

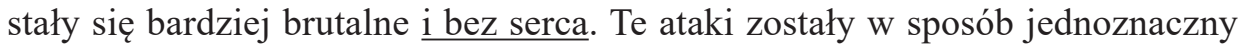
skierowane przeciwko tradycyjnemu małżeństwu i rodzinie. W przeciwieństwie do chrześcijańskiej wizji małżeństwa i rodziny współczesne mass media czy środowiska lewicowe próbują kreować obraz rodziny achrześcijańskiej, sprzeczny z prawem naturalnym i prawem Bożym. Dokonuje się to wszystko poprzez propagowanie, promowanie czy lansowanie tzw. wolnych związków, związków partnerskich, czynnego homoseksualizmu, rozwiązłości seksualnej, małżeństwa bez dzieci, pornografii, antykoncepcji, aborcji, jak również przez podważanie i ośmieszanie znaczenia przysięgi małżeńskiej.

Dostrzegamy, jak próbuje się zrównywać prawa związków homoseksualnych z prawami małżeństwa, tym samym sprowadzając tradycyjną rodzinę do stereotypu. Chrześcijanie, w kontekście narastających zagrożeń, są zobowiązani do tego, aby w współczesnym świecie walczyć i ukazywać prawdziwą oraz zdrowo funkcjonującą rodzinę, której obraz jest bardzo często fałszowany przez propagowane błędne ideologiczne hasła. To właśnie niezrozumienie istoty małżeństwa i rodziny, a także zanik świadomości religijnej czy też „letniość” i bierność wśród wiernych prowadzi do wdrażania w życie społeczne tego typu wypaczeń. W tym ataku na tradycyjną instytucję małżeństwa i rodziny szczególną rolę w jej obronie odgrywają duszpasterze. O tym zadaniu przypomniał w przesłaniu do polskich biskupów Ojciec Święty, Franciszek, który powiedział: „Niech rodziny zawsze znajdą w duszpasterzach wsparcie autentycznych ojców i przewodników duchowych, którzy będą je chronili przed zagrożeniami negatywnych ideologii i pomagali stawać się silnymi Bogiem i Jego miłością" . Papież w swoim nauczaniu o rodzinie i małżeństwie nie omija trudnego tematu, jakim są współczesne zagrożenia rodziny. Wyraźnie to podkreśla, pisząc w adhortacji apostolskiej Evangelii gaudium, iż ,postmodernistyczny i zglobalizowany indywidualizm sprzyja stylowi osłabiającego wzrost i stabilność więzi między osobami i deformującego więzi

1 Franciszek, Przemówienie papieża Franciszka do biskupów polskich, w: http://www.radiomaryja.pl/kosciol/przeslanie-papieza-franciszka-do-polskich-biskupow/ (10.04.2021). 
rodzinne"2. To wszystko skłania do podjęcia nie tylko osobistej, ale wspólnotowej refleksji nad znaczeniem wartości małżeństwa i rodziny chrześcijańskiej. Z pomocą przychodzi papież Franciszek, który tematowi małżeństwa i rodziny poświęca wiele miejsca w swoim nauczaniu. Podkreśla tym samym wartość, jaką odgrywa rodzina w życiu każdego człowieka, uwrażliwiając na niebezpieczeństwa, na jakie narażona jest rodzina, jednocześnie ukaząc wartość, jaką stanowi małżeństwo i rodzina chrześcijańska.

\section{TRUDNOŚCI W ROZUMIENIU POJĘCIA ŚWIĘTOŚCI.}

Słowo „świętość”, „bycie świętym”, w dzisiejszym świecie jest pojęciem rozumianym bardzo często niewłaściwie. Możemy „świętość” interpretować w wielu znaczeniach, np. jako istotę będącą przedmiotem kultu, w kontekście świętości (sacrum), w odniesieniu do świętości (nietykalna świętość, relikwia, obiekt kultu) oraz jako określenie czegoś przynoszącego szczęście (amulet, talizman). Tak szeroko pojmowany termin powoduje bardzo często niepoprawną jego interpretację, co może skutkować pewnym chaosem. W naszej analizie odwołamy się do świętości, która staje się powszechną drogą do zbawienia. W odniesieniu do osoby religijnej również napotykamy na różnego rodzaju, nie do końca trafne wnioski czy też interpretacje. Bardzo często słowo święty w dzisiejszym świecie staje się archaizmem, słowem niemodnym, nie na czasie. Kojarzy się z czymś nieosiągalnym, przekraczającym ludzkie siły i możliwości. Gdy mówimy o świętych czy świętości życia, to tkwi w nas takie przekonanie, iż jest ona zarezerwowana tylko dla ludzi wybranych w sposób szczególny przez Boga.

Papież Franciszek w adhortacji Gaudete et exultate przypomina o powszechnym powołaniu do świętości, ukazując tym samym właściwe znaczenie tego słowa. Celem powyższej adhortacji jest przypomnienie o tym powołaniu, próba ujęcia go w aktualnym kontekście, z jego zagrożeniami, wyzwaniami i możliwościami. Sam Pan Jezus zaprasza każdego do świętości życia słowami: „Bądźcie więc wy doskonali, jak doskonały jest Ojciec wasz niebieski” (Mt 4, 48). Warto zauważyć, iż skoro Pan Jezus wzywa swoich uczniów do bycia świętymi, to jest to zadanie do zrealizowania i wykonania. Ojciec Święty podkreśla, że świętość nie jest zarezerwowana tylko dla wybranych czy jednostek. Franciszek ukazuje błędne myślenie, iż świętość można wyłącznie osiągnąć na drodze życia kapłańskiego czy zakonnego, poprzez możliwości oddalenia się od powszednich zajęć, aby tym samym większość dnia poświęcić rozmowie z Bogiem. Papież ukazuje, że każdy ma swoją drogę, jedyną i niepowtarzalną, wiodącą ku zbawieniu. Możemy powiedzieć, że nie ma lepszych czy gorszych dróg, jest tylko moja droga do świętości.

2 Tenże, Adhortacja apostolska ,Evangelii gaudium”, 66. 
Bez względu na to, kim jestem, jakie powołanie realizuję w swoim życiu, czy to w małżeństwie, w kapłaństwie, życiu zakonnym, najważniejsze jest, aby na tej drodze realizować miłość. Świętości nie można od nikogo skopiować, chociaż przykłady świętych mogą nam pomóc wejść i odszukać własną drogę ku świętości. Życie świętych ma być dla nas źródłem motywacji i pobudzać do działania, lecz nie poprzez ich kopiowanie, ale rozeznając własną drogę ${ }^{3}$.

Papież wzywa do dawania radosnego świadectwa poprzez wypełnianie swoich codziennych obowiązków tam, gdzie się znajdujemy. ${ }^{4}$ Jak pisze, są to tzw. ,'święci z sąsiedztwa', świętość osób, które żyją blisko nas i są odblaskiem obecności Boga"5. Franciszek wskazuje na potrzebę zachowania właściwych proporcji pomiędzy modlitwą a aktywnością. Jednakże bardzo ważne jest, aby to Duch Święty przenikał całe nasze jestestwo. ${ }^{6}$ Zwraca też uwagę na to, aby nie bać się świętości i pozwolić prowadzić się Duchowi Świętemu. Owa świętość jedynie sprawi, że staniemy się bardziej ludzcy. Nie odbierze radości i sił do życia, ale jeszcze ich przymnoży. ${ }^{7}$ Do tego zachęcał również poprzednik papieża Franciszka, Benedykt XVI, który kończąc cykl katechez o świętych, wezwał do tego, aby nie lękać się dążenia do doskonałości, ku Bogu. Człowiek nie powinien bać się tego, iż Bóg zażąda od człowieka rzeczy niemożliwych, ale w tym wszystkim, co robimy, powinniśmy kierować się Jego słowem, nawet wtedy, gdy czujemy się zbyt mali czy też grzeszni. To Bóg swoją mocą, miłością umocni to, co jest słabe, aby stało się mocne ${ }^{8}$. Nie sposób również nie przywołać znamienitych słów św. Jana Pawła II, który swoim przykładem życia pokazał nam, jak dojść do świętości: „Musicie od siebie wymagać, nawet gdyby inni od Was nie wymagali”.

Franciszek analizuje w Gaudete et exsultate błogosławieństwa ewangeliczne, które są jakby „dowodem tożsamości chrześcijanina”, a więc kreślą obraz osoby świętej ${ }^{10}$. Papież naucza, że „słowo 'szczęśliwy' lub 'błogosławiony' staje się synonimem słowa 'święty', ponieważ wyraża, że osoba, która jest wierna Bogu i żyje Jego słowem, osiąga prawdziwe szczęście, dając siebie w darze" ${ }^{11}$. Rozważając kazanie Jezusa na górze, papież ukazuje istotę bycia świętym. Mówi nam, co jest świętością i na czym ona polega. Należy zauważyć, że realizacja tych błogosławieństw wcale nie jest zadaniem łatwym. Realizacja ośmiu błogosła-

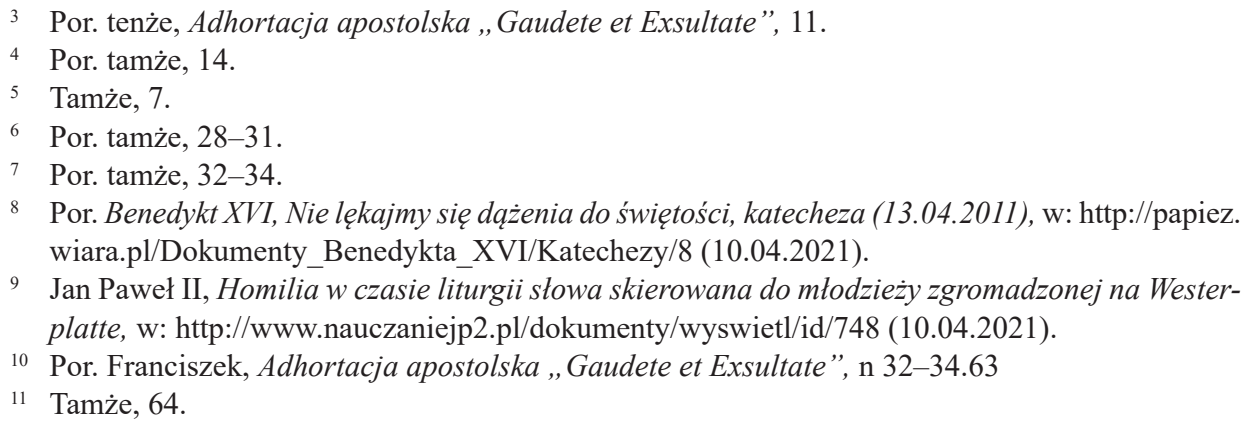

10 Por. Franciszek, Adhortacja apostolska ,Gaudete et Exsultate”, n 32-34.63

11 Tamże, 64. 
wieństw, które prowadzą do szczęśliwego, świętego i udanego życia, wymaga płynięcia pod prąd współczesnych tendencji życia dalekiego czy wręcz wrogiego wobec Boga. Drogą do świętości w świetle Bożych błogosławieństw jest zatem: bycie ubogim w sercu (p. 70), reagowanie z pokorną łagodnością (p.74), umiejętność płakania z innymi (p. 76), głodne i spragnione poszukiwanie sprawiedliwości (p. 9), miłosierne postrzeganie i działanie (p. 82), zachowywanie serca w czystości od wszystkiego, co plami miłość (p. 86), rozsiewanie pokoju wokół nas (p. 89) oraz akceptowanie codziennie drogi Ewangelii, pomimo że droga ta przynosi problemy (p. 95).

Franciszek nie tylko rysuje obraz świętego na podstawie Chrystusowych błogosławieństw, ale jeszcze wymienia wartości duchowe, które cechują świętego. Jak podkreśla papież, są one niezbędne do zrozumienia stylu życia, do którego wzywa Bóg na drodze do świętości ${ }^{12}$. Pierwszymi cechami świętości, o których mówi Franciszek, jest cierpliwość oraz łagodność. Konkretne ich urzeczywistnienie może nastąpić, gdy człowiek trwa w bliskiej relacji z Bogiem, który Go kocha i przychodzi z pomocą. To zanurzenie w Jezusie pozwala znieść wszelkie niewygody, przeciwności czy też wrogość ze strony innych ludzi, jak również umacnia w trwaniu w dobru. Kolejnymi cechami świętości, które wymienia papież, są radość i poczucie humoru oraz śmiałość i zapał.

Człowiek ze swej natury jest istotą społeczną, dlatego potrzebuje drugiego człowieka. Żyje w relacji, nawiązuje kontakty z innymi ludźmi i buduje je. Ojciec Święty ukazuje, że to właśnie wspólnota jest drogą, na której człowiek się uświęca. Wspólnota jest miejscem, gdzie osoba może wzrastać w wierze, rozwijać się duchowo, ćwiczyć się w cnotach. Pan Jezus sam powiedział: „Bo gdzie są dwaj albo trzej zebrani w imię moje, tam jestem pośród nich" (Mt 18,20). Wspólnota jest zatem miejscem doświadczenia żywego Boga, w Jego słowie czy sprawowanej Eucharystii, a także poprzez okazywanie sobie drobnych dowodów miłości, które przejawiają się we wzajemnej trosce o siebie. To spotkanie nie tylko przemienia nas wewnętrznie, ale sprawia, że stajemy się dla innych braćmi ${ }^{13}$. Papież przypomina, że drogą świętości jest „stała otwartość na transcendencję, wyrażająca się w modlitwie i adoracji”"

W Gaudete et exsultate Franciszek ukazuje drogę do świętości, która jest nieustaną walką z tym, który próbuje nas odwieść od tego, co święte. Franciszek przypomina o realnym działaniu złego ducha, wobec którego należy zachować czujność. Zarazem podkreśla wartość tej niełatwej, ale zarazem pięknej walki, jaką musi toczyć człowiek każdego dnia. Jak pisze papież, to ona pozwala nam świętować każde nasze zwycięstwo, w którym to zwyciężył Bóg, a tym samym

12 Por. tamże, 110.

13 Por. tamże, 41-142.145.

14 Tamże, 147. 
dobro, prawda, sprawiedliwość ${ }^{15}$. Franciszek podkreśla, że w tej walce nie jesteśmy sami. Jako broń wymienia: „wiarę wyrażającą się w modlitwie, rozważanie słowa Bożego, sprawowanie Mszy świętej, adorację eucharystyczną, sakrament pojednania, uczynki miłosierdzia, życie wspólnotowe, zaangażowanie misyjne" ${ }^{\text {"16}}$. Ojciec Święty, ukazując drogę świętości jako źródło pokoju i radości, które są owocem Ducha Świętego, przypomina o ciągłej gotowości stawania do walki ze złem, zachowania czujności, a nade wszystko trwania przy Chrystusie. W tym kontekście przestrzega przed zepsuciem duchowym, którego główną przyczyną jest tzw. letniość duchowa ${ }^{17}$. W adhortacji Gaudete et exsultate papież wskazuje różnych świętych, których postawa powinna nas zachęcać do podążania ku doskonałości. Jako główną przewodniczkę w drodze do świętości Franciszek podaje przykład Maryi, która nam na tej drodze towarzyszy ${ }^{18}$.

Reasumując, dostrzegamy, że powołanie do świętości jest powszechne, więc nie zarezerwowane tylko dla nielicznych. Święci to nie tylko ci, którzy są beatyfikowani lub kanonizowani, jak podkreśla Franciszek, ale świętość urzeczywistnia się w ludzie Bożym, a więc w naszych rodzinach, wśród najbliższych, przyjaciół czy też sąsiadów. Ta świętość przejawia się w prostych, małych gestach życia codziennego, przepełnionych miłością. Celem nauczania Ojca Świętego jest przywrócenie i ukazanie świętości jako drogi w życiu codziennym. Bywa bowiem, że tej świętości czasami nie doceniamy czy też jej nie pragniemy z powodu zafałszowanego obrazu. Jak pisze Franciszek, to właśnie świętość jest najpiękniejszym obliczem Kościoła.

\section{2. ŚWIĘTOŚĆ ZWIĄZKU MAEŻEŃSKIEGO I RODZINY}

Papież Franciszek w swoim nauczaniu bardzo znaczącą uwagę poświęca małżeństwu i rodzinie. Ukazuje on obraz współczesnej rodziny, nie pomijając zagrożeń, z którymi musi zmierzyć się chrześcijański ideał rodziny i małżeństwa. W swoim nauczaniu, jednakże wbrew różnym opiniom i spekulacjom mediów, Ojciec Święty odwołuje się do chrześcijańskiej nauki i stoi na straży tradycyjnej nauki Kościoła o nierozerwalności i świętości małżeństwa i rodziny.

Ukazując źródła świętości małżeństwa, warto zwrócić uwagę na zagrożenia współczesnej rodziny czy małżeństwa, o których pisze Franciszek. Jednym z przymiotów małżeństwa jest jego nierozerwalność. Małżonkowie, składając sobie przysięgę małżeńską, zobowiązują się wytrwać w tym związku na dobre i złe. Papież dostrzega, że „,coraz mniej poważnie traktuje się rozwijanie solidnej i owoc-

15 Por tamże, 158.

16 Tamże, 162.

17 Por. tamże, 164.

18 Por. tamże, nr 176. 
nej relacji miłości: w zdrowiu i chorobie, w bogactwie i ubóstwie, na dobre i na złe"19. W czasie głębokiego kulturowego kryzysu Franciszek wskazuje, iż główną przyczyną osłabienia więzi małżeńskich, a tym samym relacji między członkami rodziny, jest promowany styl życia, negujący jakiekolwiek prawdy obiektywne, odrzucający prawo moralne, odwołując się tylko do swoich indywidualnych przekonań ${ }^{20}$. Nie można pominąć kwestii, iż ta ideologia postmodernistyczna jednoznacznie uderza w nierozerwalność małżeństwa, promując tzw. wolne związki, życie na próbę, życie bez odpowiedzialności i jakichkolwiek zobowiązań.

Dostrzegamy zatem, że to właśnie tradycyjna rodzina, która stała się celem ataków, stanowi dla człowieka miejsce prawdziwego wzrostu. To w niej człowiek przychodzi na świat, dojrzewa, wychowuje się, przygotowuje się do życia w społeczeństwie, uczy się właściwych postaw, wzorców osobowościowych, uczy się wartości religijnych, kulturowych. Jest ona miejscem, „gdzie człowiek uczy się współżycia w różnorodności i przynależności do innych oraz gdzie rodzice przekazują dzieciom wiarę"21. Kościół, w odróżnieniu od ideologii, jaką głosi współczesny świat, promując wolne związki, wskazuje na głębię, trwałość i nierozerwalność wspólnoty małżeńskiej. Zwraca uwagę, iż takie błędne spojrzenie na małżeństwo burzy rodzinę i uderza w prawidłowy rozwój oraz jej funkcjonowanie, a w konsekwencji całego społeczeństwa. Dlatego bardzo ważnym zadaniem, jak podkreśla Franciszek, jest wspierać rodziny, które ,przeżywają swoje małżeństwo jako przestrzeń, w której objawia się miłość Boża; aby bronić świętości życia, każdego życia, by bronić jedności i nierozerwalności węzła małżeńskiego, jako znaku łaski Bożej i ludzkiej zdolności do kochania na serio"22. Poruszając kwestię nierozerwalności związku małżeńskiego, warto przytoczyć naukę papieża, którą zawarł w encyklice Lumen fidei, ujmując rodzinę jako: ,trwały związek mężczyzny i kobiety w małżeństwie, powstały z miłości, będącej znakiem i obecnością miłości Bożej"23. Papież Franciszek bardzo często porównuje rodzinę i małżeństwo do obrazu Trójcy Świętej, do relacji, jakie zachodzą pomiędzy Ojcem, Synem i Duchem Świętym, gdy pisze: „małżonkowie są obrazem Boga, obydwoje, mężczyzna i kobieta. Nie sam jeden mężczyzna, czy tylko kobieta, ale obydwoje są obrazem Boga" ${ }^{24}$ Tym samym podkreśla jedność małżonków, która swoje źródło ma w jedności Osób Trójcy Świętej. W jednej ze swoich katechez, zamykających

19 Tenże, Homilia wygłoszona 4 X 2015 podczas Mszy świętej inaugurującej XIV Zgromadzenie Zwyczajne Synodu Biskupów, „, L’Osservatore Romano” wyd. pol., 36 (2015) nr 10, s. 15

20 Por tenże, Adhortacja apostolska „Evangelii gaudium”, 66.

21 Tamże, 66.

22 Tenże, Homilia wygłoszona 4 X 2015 podczas Mszy świętej inaugurującej XIV Zgromadzenie Zwyczajne Synodu Biskupów, dz. cyt., s.16

23 Tenże, Encyklika „Lumen fidei”, Rzym 2013, 52.

24 Tenże, Wspólnota malżeńska odblaskiem jedności Trójcy, katecheza (02.04.2014), w: http://papiez. wiara.pl/doc/1944150.Wspolnota-malzenska-odblaskiem-jednosci-Trojcy (15.03.2021). 
cykl o sakramentach, omawiając sakrament małżeństwa, odwołał się do aktu stworzenia człowieka, ukazując tym samym, iż to w małżonkach dostrzega się obraz komunii trzech Osób Trójcy Przenajświętszej. Franciszek nazywa małżeństwo „ikoną miłości Boga i człowieka”, która przejawia się w doskonałej jedności i miłości Ojca, Syna i Ducha Świętego. Na uwagę zasługuje fakt, iż poprzednik Franciszka, Benedykt XVI, w jednym ze swoich rozważań przed modlitwą Aniot Pański w kontekście małżeństwa użył tego samego sformułowania, nazywając „rodzinę ludzką ikoną Boga”, uzasadniając to przyjściem na świat Syna Bożego, które dokonało się w konkretnej ludzkiej rodzinie. Podkreślił dalej w swoim rozważaniu, że „rodzina ludzka w pewnym sensie jest ikoną Trójcy, zarówno ze względu na miłość międzyosobową, jak i płodność miłości”25. Nie sposób nie wspomnieć, że według Kodeksu Prawa Kanonicznego „małżeńskie przymierze, przez które mężczyzna i kobieta tworzą ze sobą wspólnotę całego życia, zostało między ochrzczonymi podniesione przez Chrystusa do godności sakramentu"26. Papież, mówiąc o świętości małżeństwa, porównuje je z obrazem miłości Chrystusa i Kościoła. Tak jak Jezus umiłował Kościół, oddając swoje życie za jego członków, tak samo małżonkowie mają czynić ze swojego życia dar dla drugiego człowieka. Właśnie taka postawa ma prowadzić małżonków do urzeczywistniania się miłości Boga $w$ ich życiu. Franciszek podkreśla, że ta analogia jest niedoskonała. Małżonkowie, wchodząc w związek małżeński, zapraszają Jezusa do swojej wspólnoty. Jest to relacja miłości, a Tym, który ją udoskonala, jest Chrystus ${ }^{27}$.

Odwołując się do Księgi Rodzaju, Franciszek dostrzega więź, jaka łączy mężczyznę i kobietę, którzy zostali stworzeni na obraz i podobieństwo Boże - „Na obraz Boży stworzył ich mężczyzną i kobietą" (Rdz 1,27-28). Idąc dalej w biblijnych rozważaniach, podkreśla jedność małżonków w oparciu o słowa z Księgi Rodzaju: „dlatego to mężczyzna opuszcza ojca swego i matkę swoją i łączy się ze

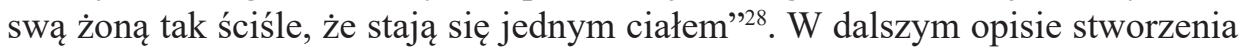
możemy zauważyć, że małżeństwo otrzymało od Boga specjalne błogosławieństwo, po czym „Bóg pobłogosławił im”. To błogosławieństwo urzeczywistnia się w przekazie nowego życia, podkreślając płodność jako dar, a każde życie jako świętość. Małżonkowie są wezwani zatem do daru z siebie w miłości i przekazywaniu życia. Jak naucza Franciszek: „Stwórca uczynił mężczyznę i kobietę współpracownikami swego stworzenia, a jednocześnie uczynił ich narzędziami swej miłości, powierzając ich odpowiedzialności przyszłość rodziny ludzkiej poprzez

25 Benedykt XVI, Rodzina ludzka ikoną Boga, Anioł Pański (27.12.2009), „Sprawy Rodziny, Kwartalnik Duszpasterstwa Rodzin” nr 89/1/2010, s.52.

26 KPK, kan. 1055.

27 Por. Franciszek, Adhortacja apostolska „Amoris Laetitia”, 71-73.

28 Por. tenże, Dwoje w jednym. Audiencja generalna (2.04.2014), „L'Osservatore Romano” wersja polska 35(2014), nr 5, s. 37. 
przekazywanie życia"29. Miłość małżonków zatem powinna być płodna i urzeczywistniać się we wspólnym dziele kontynuacji stworzenia. Papież zauważa problem małżeństw, które z różnych przyczyn nie mogą mieć własnego potomstwa. Ojciec Święty podkreśla, że to nie czyni ich małżeństwo niepłodnym. Wskazuje, iż drogą, aby uczynić swoje małżeństwo płodnym, jest zdecydowanie się małżonków na adopcję $e^{30}$. Tym samym papież zauważa, że każde życie jest darem, które powinno wzrastać w rodzinie i być przez nie otoczone miłością i troską ${ }^{31}$.

Poruszając temat świętości życia, należy podkreślić, że dla papieża rodzina jest nie tylko „wspólnotą życia”, ale również jest ona oparta na małżeństwie. Według papieża małżeństwo to ,jakby pierwszy sakrament tego, co ludzkie, gdzie osoba odkrywa samą siebie, sama siebie rozumie w relacji do innych i w relacji do miłości, którą potrafi przyjmować i dawać" ${ }^{32}$. Widzimy zatem, że to właśnie rodzina jest środowiskiem i miejscem, w którym realizuje się miłość, wyrażająca się we wzajemnej miłości małżonków do siebie oraz miłości rodziców do dzieci i odwrotnie, jak również miejscem pogłębiania więzi z pozostałymi członkami rodziny, pamiętając w sposób szczególny o osobach starszych. Wartość świętości rodziny i małżeństwa w swoim nauczaniu podkreślał św. Jan Paweł II, do którego bardzo często odwołuje się papież Franciszek, pisząc, że „rodzina jest kolebką życia i miłości, gdzie człowiek 'rodzi' się i 'wzrasta', jest podstawową komórką społeczeństwa. Tę wspólnotę należy otaczać specjalną opieką, zwłaszcza wtedy, gdy ludzki egoizm, kampanie antyprokreacyjne, polityka totalitarna, a także nędza i ubóstwo materialne, kulturalne i moralne, jak również mentalność hedonistyczna i konsumpcyjna, niszczą źródło życia, ideologie zaś i rozmaite systemy, z którymi łączą się różne formy obojętności i niechęci, atakują właściwą rodzinie funkcję wychowawczą" "33. Reasumując, należy stwierdzić, że małżeństwo jest powołaniem, które zostało wpisane w naturę mężczyzny i kobiety. Jest ono darem, ale zarazem i zadaniem. Jest ono spotkaniem małżonków z Chrystusem, który jest źródłem ich świętości i łaski. Możemy wskazać, że świętość małżeństwa zawiera się w przymiotach samego związku, którymi jest sakramentalność, jedność, nierozerwalność, wierność i otwartość na życie.

\footnotetext{
29 Tenże, Adhortacja apostolska „,Amoris Laetitia”, 81.

30 Por. tamże, 82.

31 Por. tamże.

32 Tenże, W rodzinie uczymy się kochać i bronić życia. Audiencja dla uczestników zgromadzenia plenarnego Papieskiej Rady ds. Rodziny (5.10. 2013), „L'Osservatore Romano” wersja polska 34(2013), nr 12, s. 28.

33 Jan Paweł II, Adhortacja apostolska ,Christifideles Laici”, 40.
} 


\section{MAEŻEŃSTWO DROGĄ DO ŚWIĘTOŚCI}

Małżeństwo jest drogą, na której małżonkowie powinni uświęcać swoje życie poprzez doskonalenie się w miłości, która wymaga „wielkodusznego daru z siebie" ${ }^{34}$. Miłość małżeńska wymaga od małżonków poświęcenia, wyrzeczenia, pewnej ofiary z siebie, zrezygnowania bardzo często z własnego indywidualistycznego i egoistycznego myślenia. Franciszek ukazuje miłość między żoną a mężem nie w ujęciu jakichś wzniosłych definicji teologiczno-moralnych, ale opisuje ją jako coś, co przyniesie małżonkom radość. Jest to radość, którą małżonkowie powinni odkrywać nie tylko w chwilach bezproblemowych, ale również w trudach i smutkach dnia codziennego. Takie patrzenie na małżeństwo prowadzi małżonków do wzrostu w ich świętości. Ten wzrost zarazem powinien urzeczywistniać się w trosce o siebie, „świadcząc sobie wzajemną pomoc i posługę" ${ }^{35}$. Widzimy, iż prawdziwa miłość przejawia się we wzajemnej odpowiedzialności za siebie. Papież przypomina, że w codziennym życiu i okazywaniu sobie wzajemnej miłości nie można zapomnieć o takich słowach jak proszę, dziękuję i przepraszam. Jak podkreśla Franciszek, są to słowa, które wypowiedziane w odpowiednim momencie umacniają i scalają miłość małżonków, jak również całe życie rodzinne ${ }^{36}$.

Ojciec Święty ukazuje rodzinę jako drogę, która jest procesem dojrzewania ku doskonałości. Budowanie jest zatem procesem długofalowym, który wymaga cierpliwości i zaakceptowania go takim, jakim jest na danym etapie wzrastania ku świętości. Ta dojrzałość między innymi przejawia się we wspólnym podejmowaniu decyzji dotyczących przyszłości, wizji swojego małżeństwa i życia rodzinnego ${ }^{37}$. Franciszek podkreśla, że wspólne spędzanie czasu z poszczególnymi członkami rodziny prowadzi do pogłębienia tych więzi ${ }^{38}$. Papież podaje małe gesty, które czynione z miłością, przyczyniają się do budowania więzi małżeńskich: „warto zawsze rano pocałować się nawzajem, błogosławić jedno drugie wieczorem, czekać na drugą osobę i powitać ją, gdy wraca, czasami wyjść razem, dzielić się pracami domowymi" ${ }^{39}$. Papież dostrzega wartość modlitwy i znaczącą jej rolę w życiu małżeńskim i rodzinnym, pisząc, że: „żadna wspólnota chrześcijańska nie może się rozwijać bez wsparcia wytrwałej modlitwy" ${ }^{40}$. Widzimy, że to, co przy-

34 Franciszek, Adhortacja apostolska „Amoris Laetitia”, 220.

35 Por. tamże, 126.

36 Por. tamże, 133.

37 Por. tamże, 118.

38 Por. tamże, 224.

39 Tamże, 226.

40 Tenże, Wezwanie do modlitwy, do wiary i do dawania świadectwa, Homilia podczas Mszy św. w uroczystość Ś więtych Apostolów Piotra i Pawła (29.06.2015), w: https://opoka.org.pl/biblioteka/W/WP/franciszek_i/homilie/pp_29062015.html (10.03.2021). 
czynia się do zbudowania relacji z Bogiem, tym samym staje się źródłem budowania więzi małżeńskich i rodzinnych. Modlitwa jest jedną z istotnych cech, którą powinna odznaczać się rodzina chrześcijańska. To modlitwa, zdaniem papieża, stanowi fundament życia duchowego małżeństwa i rodziny. Świadczą o tym słowa: „módlcie się za siebie nawzajem: mąż za żonę, żona za męża, obydwoje za dzieci, dzieci za rodziców, za dziadków (...) Trzeba się modlić za siebie wzajemnie. To jest modlenie się w rodzinie i ta modlitwa umacnia rodzinę"41. Modlitwa zatem staje się jedną z dróg, która prowadzi do uświęcenia małżonków i życia rodzinnego. Gdy małżonkowie się modlą, zostają jakby włączeni w dialog i miłość Trójjedynego Boga. Franciszek mocno akcentuje, że tym, co udoskonala miłość i relacje rodzinne, jest miłość, o której pisze św. Paweł w Hymnie o miłości ${ }^{42}$.

Kolejnym środkiem niezbędnym, by rozwijać się, a tym samym móc wyrazić swoją miłość w małżeństwie czy życiu rodzinnym, jest dialog. Wymaga on jednak ze strony małżonków zaangażowania i systematycznej pracy. Papież podaje kilka wskazówek, czyniących dialog konstruktywnym i owocnym. Dostrzega wartość słuchania przed mówieniem. Rozpoczynając dialog, należy pamiętać, aby unikać oceny, aby bardziej starać się zrozumieć drugą stronę, dlaczego tak a nie inaczej postąpiła. Nie można zapomnieć, aby podczas rozmowy nie podzielić się swoimi własnymi przeżyciami, które prowadzą do budowania wspólnych wartości, zaufania i jedności ${ }^{43}$. Franciszek też podkreśla wartość wspólnoty stołu, a więc znaczenie spożywania wspólnych posiłków z całą rodziną. Stół to miejsce, które nie powinno być tylko miejscem konsumpcji, ale dzielenia się sobą, swoimi doświadczeniami, spostrzeżeniami, radościami czy nawet smutkami. Stół jest miejscem spotkania z drugim człowiekiem i przyjęcia postawy otwartej na ten dar. Papież dostrzega pewne niebezpieczeństwo, które zamyka ludzi na siebie. Tymi zagrożeniami są m.in. urządzenia telefoniczne, Internet, które użytkowane w sposób niewłaściwy prowadzą do osłabienia więzi rodzinnych, gdy stają się one ważniejsze niż spotkanie z drugim człowiekiem.

Wspólnota stołu jest jakąś analogią Eucharystii. Właśnie rodzinny stół staje się centralnym miejscem w domu, przy którym rodzina może się razem spotkać. Czyniąc analogię do powyższego przykładu, możemy powiedzieć, że Ołtarz Chrystusowy staje się dla małżonków i dzieci spotkaniem z Jezusem, który karmi nas swoim Słowem oraz Ciałem i Krwią Pańską. Jak zauważa Franciszek: „Msza św. jest modlitwą, najwspanialszą, najbardziej wzniosłą, a zarazem 'konkretną'. Jest to bowiem spotkanie miłości z Bogiem poprzez Jego Słowo oraz Ciało i Krew

41 Tenże, Miłość cierpliwa, która rodzi radość. Homilia Ojca Świętego podczas Mszy św. dla rodzin (27.10.2013), „L'Osservatore Romano” wersja polska 34(2013), nr 12, s.12.

42 Por. tenże, Adhortacja apostolska „,Amoris Laetitia”, 89.

43 Por. tamże, 136-139. 
Jezusa"44. Pan Jezus pragnie nam w Eucharystii przekazać swoją zwycięską miłość paschalną. Przyjęcie jej sprawia, że możemy „,kochać, jak On nas umiłował, oddając swe życie (...) mogę dać siebie w pełni drugiemu"45. Tym samym udoskonala ona małżonków do czynienia z siebie daru oraz wzajemnego oddania się sobie w sposób bezinteresowny. To właśnie wspólny udział małżonków w Eucharystii przyczynia się do trwałości związku. Eucharystia, która jest sakramentem miłości, uświadamia małżonkom ich wzajemną odpowiedzialność za siebie i za pozostałych członków rodziny. Eucharystia powinna stanowić dla małżonków źródło do działania i stawiania czoła trudom dnia codziennego. Zdaniem papieża Franciszka, „niedzielne spotkanie z Panem daje nam siłę do życia dniem dzisiejszym z ufno-

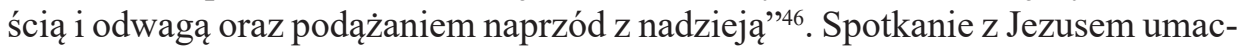
nia zatem małżonków do podejmowania codziennych zadań z miłością.

Reasumując, dostrzegamy, że małżeństwo jest jedną z dróg, na której człowiek może realizować swoje powołanie do świętości. To powołanie do świętości jest zarazem powołaniem do miłości. Bóg nie stworzył człowieka jako osoby samotnej czy do życia w samotności, ale do życia we wspólnocie. Zostaliśmy stworzeni na obraz, podobieństwo Boże, a tym samym stworzeni do budowania relacji międzyludzkich i ze swoim Stwórcą. Sakramentalne Małżeństwo staje się dla małżonków miejscem otrzymywania łask, które nieustannie płyną z obecności Chrystusa. Jak mogliśmy zauważyć, papież w swoim nauczaniu ukazuje drogę do świętości jako drogę drobnych gestów. Wśród codziennych obowiązków małżonkowie nie powinni zapominać o miłych słowach, prostych gestach dobroci, liścikach miłosnych. Czasem tak niewiele potrzeba, by odświeżyć wzajemną więź, by druga osoba poczuła się adorowana i doceniona. Należy pamiętać o rozmowie, dialogu, szczerości, dzieleniu się przeżyciami, doświadczeniami. Warto zatem już od pierwszych chwil bycia razem nie bać się inwestować we własne małżeństwo, które jest „prawdziwym i autentycznym powołaniem” oraz „światłem w ciemności świata".

44 Tenże, Eucharystia najwspanialsza modlitwa, cykl katechez Ojca Świętego o Eucharystii (15.11.2017), w: http://papiez.wiara.pl/doc/4316519.Eucharystia-najwspanialsza-modlitwa (10.03.2021).

45 Tenże, Msza św. pamiątka Paschy, cykl katechez Ojca Świętego (22.11.2017), w: http://papiez. wiara.pl/doc/4331585.Kazda-Msza-sw-jest-pamiatka-Paschy (10.03.2021).

46 Tenże, Niedziela jest pierwotnym dniem światecznym, cykl katechez Ojca Świętego (13.12.2017), w: http://papiez.wiara.pl/doc/4374151.Niedziela-jest-pierwotnym-dniem-swiatecznym (10.03.2021). 


\section{PODSUMOWANIE}

Rodzina, która stała się dziś adresatem, celem wielu ataków, godzących w człowieczeństwo, jest jedynym miejscem, w którym człowiek może rozeznać swoje powołanie i rozwijać swoje człowieczeństwo, które realizuje się ostatecznie w miłości. Celem bowiem ideologii wrogich rodzinie jest przeforsowanie błędnych, zgubnych, patologicznych poglądów, kosztem niszczenia tradycyjnej rodziny, która z samego faktu stworzenia przez Boga jest już święta. W powyższym rozważaniu ten problem został zarysowany. Wymaga on podjęcia jeszcze głębszej refleksji, zastanowienia się nad tym, jakie środki należałoby przedsięwziąć, aby uchronić rodzinę i małżeństwo od nasilających się antychrześcijańskich i poniżających godność człowieka ideologii. Według papieża Franciszka gwarantem wzajemnych więzi pomiędzy członkami rodziny jest modlitwa. Warto wspomnieć, że św. Jan Paweł II często podkreślał, że jednym z najskuteczniejszych środków w walce z tymi zagrożeniami jest powrót do modlitwy, wskazując na moc modlitwy różańcowej w rodzinach chrześcijańskich. O tym przypomniał w Liście Apostolskim Rosarium Virginis Mariae.

\section{Bibliografia}

Benedykt XVI, Ludzka rodzina ikoną Boga, Anioł Pański (27.12.2009), „Sprawy Rodziny, Kwartalnik Duszpasterstwa Rodzin” nr 89/1/2010, s. 52.

Benedykt XVI, Nie lękajmy się dążenia do świętości, katecheza (13.04.2011), w: http://papiez.wiara.pl/Dokumenty_Benedykta_XVI/Katechezy/8 (10.04.2021).

Franciszek, Adhortacja apostolska o głoszeniu Ewangelii w dzisiejszym „Evangelii gaudium”, Rzym 2013.

Franciszek, Adhortacja Apostolska o miłości w rodzinie „Amoris Laetitia”, Rzym 2016.

Franciszek, Adhortacja Apostolska o powołaniu do świętości w świecie wspótczesnym ,, Gaudete et exsultate”, Rzym 2018

Franciszek, Dwoje w jednym. Audiencja generalna z 2.04.2014, „L'Osservatore Romano" wersja polska 35(2014), nr 5, s. 37-38.

Franciszek, Encyklika „Lumen fidei”, Rzym 2013

Franciszek, Eucharystia najwspanialsza modlitwa, cykl katechez Ojca Świętego o Eucharystii (15.11.2017), w: http://papiez.wiara.pl/doc/4316519.Eucharystia najwspanialsza-modlitwa (10.03.2021).

Franciszek, Eucharystia najwspanialsza modlitwa, cykl katechez Ojca Świętego o Eucharystii (15.11.2017), w: http://papiez.wiara.pl/doc/4316519.Eucharystia-najwspanialsza-modlitwa (10.03.2021). 
Franciszek, Homilia wygłoszona 4 X 2015 podczas Mszy świętej inaugurującej XIV Zgromadzenie Zwyczajne Synodu Biskupów, „, L'Osservatore Romano” wyd. pol., 36 (2015) nr 10, s. 15-16.

Franciszek, Miłość cierpliwa, która rodzi radość. 27 X 2013.

Homilia Ojca Świętego podczas Mszy św. dla rodzin, „L'Osservatore Romano” wersja polska 34(2013), nr 12, s. 12-13.

Franciszek, Msza św. pamiątka Paschy, cykl katechez Ojca Świętego (22.11.2017), w: http://papiez.wiara.pl/doc/4331585.Kazda-Msza-sw-jest-pamiatka-Paschy (10.03.2021).

Franciszek, Niedziela jest pierwotnym dniem światecznym, cykl katechez Ojca Świętego (13.12.2017), w: http://papiez.wiara.pl/doc/4374151.Niedziela-jest-pierwotnym-dniem-swiatecznym (10.03.2021).

Franciszek, Przemówienie papieża Franciszka do biskupów polskich, w: http:// www.radiomaryja.pl/kosciol/przeslanie-papieza-franciszka-do-polskich-biskupow/ (10.04.2021).

Franciszek, Wrodzinie uczymy się kochać i bronić życia. Audiencja dla uczestników zgromadzenia plenarnego Papieskiej Rady ds. Rodziny(25.10.2013), „L'Osservatore Romano" wersja polska 34(2013), nr 12, s. 27-29.

Franciszek, Wezwanie do modlitwy, do wiary i do dawania świadectwa. Homilia podczas Mszy św. w uroczystość Świętych Apostołów Piotra i Pawła (29.06.2015), w: https://opoka.org.pl/biblioteka/W/WP/franciszek_i/homilie/pp_29062015.html (10.05.2018).

Franciszek, Wspólnota matżeńska odblaskiem jedności Trójcy (02.04.2014), w: http://papiez.wiara.pl/doc/1944150.Wspolnota-malzenska-odblaskiem-jednosci-Trojcy (15.03.2021).

Jan Paweł II, Adhortacja apostolska o zadaniach rodziny chrześcijańskiej w świecie wspótczesnym „,Familiaris consortio”, Rzym 1981.

Jan Paweł II, Homilia w czasie liturgii stowa skierowana do młodzieży zgromadzonej na Westerplatte, w: http://www.nauczaniejp2.pl/dokumenty/wyswietl/ $\mathrm{id} / 748$ (10.04.2021).

Jan Paweł II, Posynodalna Adhortacja Apostolska o powołaniu i misji świeckich w Kościele i w świecie dwadzieścia lat po Soborze Watykańskim II ,, Christifideles laici”, Rzym 1988.

Kodeks Prawa Kanonicznego, wyd. Pallottinum, Poznań 1984. 